\title{
Spectrins and AnkyrinB Constitute a Specialized Paranodal Cytoskeleton
}

\author{
Yasuhiro Ogawa, ${ }^{1}$ Dorothy P. Schafer, ${ }^{1}$ Ido Horresh, ${ }^{2}$ Vered Bar, ${ }^{2}$ Kimberly Hales, ${ }^{1}$ Yang Yang, ${ }^{1}$ Keiichiro Susuki, ${ }^{1}$ \\ Elior Peles, ${ }^{2}$ Michael C. Stankewich, ${ }^{3}$ and Matthew N. Rasband ${ }^{1}$ \\ ${ }^{1}$ Department of Neuroscience, University of Connecticut Health Center, Farmington, Connecticut 06030, ${ }^{2}$ Department of Molecular Cell Biology, Weizmann \\ Institute of Science, Rehovot, Israel 76100, and ${ }^{3}$ Department of Pathology, Yale University, New Haven, Connecticut 06520
}

\begin{abstract}
Paranodal junctions of myelinated nerve fibers are important for saltatory conduction and function as paracellular and membrane protein diffusion barriers flanking nodes of Ranvier. The formation of these specialized axoglial contacts depends on the presence of three cell adhesion molecules: neurofascin 155 on the glial membrane and a complex of Caspr and contactin on the axon. We isolated axonal and glial membranes highly enriched in these paranodal proteins and then used mass spectrometry to identify additional proteins associated with the paranodal axoglial junction. This strategy led to the identification of three novel components of the paranodal cytoskeleton: ankyrin $\mathrm{B}, \alpha \mathrm{II}$ spectrin, and $\beta \mathrm{II}$ spectrin. Biochemical and immunohistochemical analyses revealed that these proteins associate with protein $4.1 \mathrm{~B}$ in a macromolecular complex that is concentrated at central and peripheral paranodal junctions in the adult and during early myelination. Furthermore, we show that the paranodal localization of ankyrinB is disrupted in Caspr-null mice with aberrant paranodal junctions, demonstrating that paranodal neuron-glia interactions regulate the organization of the underlying cytoskeleton. In contrast, genetic disruption of the juxtaparanodal protein Caspr2 or the nodal cytoskeletal protein $\beta$ IV spectrin did not alter the paranodal cytoskeleton. Our results demonstrate that the paranodal junction contains specialized cytoskeletal components that may be important to stabilize axon-glia interactions and contribute to the membrane protein diffusion barrier found at paranodes.
\end{abstract}

Key words: myelin; node of Ranvier; axoglial junction; scaffold; ankyrin; paranode

\section{Introduction}

Myelinated axons are subdivided into morphologically, functionally, and molecularly distinct polarized domains, including the node of Ranvier, the flanking paranodal junctions, and the adjacent juxtaparanodal region (Poliak and Peles, 2003; Salzer, 2003). Each of these domains contains unique protein complexes consisting of glial and axonal cell adhesion molecules (CAMs), ion channels, and cytoskeletal/scaffolding proteins. The mechanisms regulating the formation and maintenance of these membrane domains are just beginning to be discovered. For example, during myelination in the peripheral nervous system (PNS), the Schwann cell protein gliomedin directs clustering of the axonal CAMs neurofascin-186 (NF-186) and neuron-glia-related CAM at nascent nodes of Ranvier (Eshed et al., 2005). NF-186 in turn recruits ankyrinG, a cytoskeletal/scaffolding protein thought to be essential for the nodal localization of voltage-gated ion channels (Zhou et al., 1998; Garrido et al., 2003; Devaux et al., 2004). Nodes are further stabilized by a specialized cytoskeleton that

\footnotetext{
Received Jan. 30, 2006; revised March 22, 2006; accepted March 29, 2006.

This work was supported by National Institutes of Health Grant NS044916 (M.N.R.) and National Multiple Sclerosis Society Grant RG3102-B-3 (E.P.). E.P. is Incumbent of the Madeleine Haas Russell Career Development Chair. *Y.0. and D.P.S. contributed equally to this work.

Correspondence should be addressed to either of the following: Dr. Matthew N. Rasband, Department of Neuroscience, University of Connecticut Health Center, 263 Farmington Avenue, Farmington, CT 06032, E-mail: rasband@uchc.edu; or Dr. Michael C. Stankewich, Department of Pathology, Yale University School of Medicine, P.O. Box 208023, 310 Cedar Street, BML 150, New Haven, CT 06520, E-mail: michael.stankewich@yale.edu. DOI:10.1523/JNEUROSCI.0425-06.2006

Copyright $\odot 2006$ Society for Neuroscience $\quad$ 0270-6474/06/265230-10\$15.00/0
}

includes $\beta$ IV spectrin (Berghs et al., 2000; Lacas-Gervais et al., 2004; Yang et al., 2004). Loss of these neuron-glia interactions results in failure to cluster nodal proteins (Sherman et al., 2005).

The development and maintenance of both nodal and juxtaparanodal domains also depend on the paranodal junction formed between the paranodal loops and the axon on each side of the node of Ranvier. For example, Kv1 channels and Caspr2 invade paranodal zones in mice lacking proper axoglial junctions, indicating that paranodal junctions function as barriers to restrict the lateral diffusion of membrane proteins (Dupree et al., 1999; Bhat et al., 2001; Boyle et al., 2001; Poliak et al., 2001; Rasband et al., 2003; Rios et al., 2003). Paranodal junctions regulate the initial clustering and kinds of channels at nodes in the CNS (Rasband et al., 1999; Boiko et al., 2001; Rios et al., 2003) and are also essential for action potential conduction because they function as partial paracellular ion diffusion barriers, separating internodal periaxonal space from nodal extracellular space (Chiu and Ritchie, 1980). However, despite the importance of the paranodal junction, little is known about the proteins that are required for the assembly of this complex structure. The axonal CAMs Caspr and contactin, and glial neurofascin (NF-155), are essential and form trans-interacting heterophilic complexes (Bhat et al., 2001; Boyle et al., 2001; Gollan et al., 2003; Sherman et al., 2005), but the details of the interactions remain controversial (Charles et al., 2002; Gollan et al., 2003). Paranodal CAMs may be stabilized and anchored to the cytoskeleton. However, so far, only protein $4.1 \mathrm{~B}$ has been identified at the paranode (Ohara 
et al., 2000; Gollan et al., 2002). Here we report the identification of a macromolecular complex of three novel proteins that constitute a specialized cytoskeleton at the paranodal junction. We further demonstrate that the organization of the paranodal cytoskeleton depends on neuron-glia interactions.

\section{Materials and Methods}

Animals. Rat and mouse tissues (brain, optic nerve, and sciatic nerve) were obtained by rapidly dissecting out the tissue after killing animals with halothane. Genotypes of quivering $3 J\left(q v^{3 J}\right)$ mice were determined as described previously (Yang et al., 2004). Caspr- and Caspr2-null mice have been described previously (Gollan et al., 2003; Poliak et al., 2003). Animals were housed at the Center for Laboratory Animal Care at the University of Connecticut Health Center and the Weizmann Institute of Science in accordance with all National Institutes of Health guidelines for the humane treatment of animals.

Antibodies. The monoclonal pan NF, pan $\mathrm{Na}^{+}$channel (pan Nav), Caspr, Caspr2, contactin, 4.1B, Nav1.6, and $\beta$ IV spectrin antibodies have been described previously (Poliak et al., 1999; Gollan et al., 2002; Schafer et al., 2004; Yang et al., 2004). We generated a rabbit polyclonal pan neurofascin antibody against a small peptide (CSFIGQYTVRK) corresponding to a highly conserved cytoplasmic sequence found in all L1 CAMs. By immunoblot, the two main immunoreactive bands are NF155 and NF-186 (data not shown). By immunostaining, nodes and paranodes are strongly labeled; this immunoreactivity was blocked by preincubating the antibodies in a molar excess of the peptide immunogen (data not shown). Rat monoclonal antibodies against myelin basic protein (MBP) were purchased from Chemicon (Temecula, CA). Mouse monoclonal antibodies against ankyrinB were purchased from Zymed (San Francisco, CA). Mouse monoclonal antibodies against $\alpha \mathrm{II}$ and $\beta \mathrm{II}$ spectrin were purchased from Chemicon and BD Transduction Laboratories (San Jose, CA), respectively. For rabbit anti- $\beta$ II spectrin antibodies, a polyclonal rabbit antibody (10-D) was generated to a glutathione $S$-transferase- $\beta$ II spectrin fusion protein representing codons 1676-2204. Rabbit polyclonal antibodies specific for protein 4.1G and protein $4.1 \mathrm{~N}$ were kindly provided by Dr. Ilya Bezprozvanny (University of Texas Southwestern, Dallas, TX). The antibody against contactin used for immunoprecipitation (IP) was a mouse monoclonal antibody, K73/ 20, a gift from Dr. James Trimmer (University of California, Davis, Davis, CA). Alexa Fluor-350, Alexa Fluor-488, and Alexa Fluor-594 secondary antibodies were purchased from Invitrogen (Carlsbad, CA).

Immunostaining. Immunostaining of optic and sciatic nerves was performed as described by Schafer et al. (2004).

Membrane homogenates. Synaptosomes were prepared mostly as described previously (Tandon et al., 1998). Briefly, two mice were killed, and whole brains were dissected and homogenized in ice-cold buffer A (in mM: 320 sucrose, 1 EGTA, and 5 HEPES, pH 7.4). The homogenate was centrifuged at $1000 \times g$ for $10 \mathrm{~min}$. The supernatant was spun for 15 min at 13,000 $\times g$, and the resulting pellet was resuspended in buffer $A$. The resuspended fraction was loaded onto a discontinuous Ficoll 400 gradient [13\% (4 ml), 9\% (1 ml), 5\% (4 ml) in buffer A] and centrifuged for $35 \mathrm{~min}$ at $60,000 \times \mathrm{g}$. The $13 \%-9 \%$ interface, containing intact synaptosomes, was collected and resuspended in $3 \mathrm{vol}$ of the following (in mM): $140 \mathrm{NaCl}, 5 \mathrm{KCl}, 20 \mathrm{HEPES}, 5 \mathrm{NaHCO}_{3}, 1.2 \mathrm{Na} 2 \mathrm{HPO}_{4}, 1 \mathrm{MgCl}_{2}$, and 1 EGTA. The synaptosomal fractions were diluted 1:10 in IP buffer [20 mM HEPES, pH 7.4, 120 mm NaCl, 25 mm KCl, 2 mм EDTA, 1 mm EGTA, and 1\% TX-100 containing Protease Arrest at 1:200 (Calbiochem, La Jolla, CA)]). Alternatively, crude membrane homogenates from brain and optic nerve were prepared from freshly dissected rat tissues. All steps using membrane homogenates or its derivatives were performed at $4^{\circ} \mathrm{C}$ or on ice. Each brain was homogenized in ice-cold $0.32 \mathrm{M}$ sucrose, $5 \mathrm{~mm}$ sodium phosphate, $\mathrm{pH} 7.4$, and $1 \mathrm{~mm}$ sodium fluoride, containing $1 \mathrm{~mm}$ phenylmethylsulfonyl fluoride (PMSF), $2 \mu \mathrm{g} / \mathrm{ml}$ aprotinin, $1 \mu \mathrm{g} / \mathrm{ml}$ leupeptin, $2 \mu \mathrm{g} / \mathrm{ml}$ antipain, and $10 \mu \mathrm{g} / \mathrm{ml}$ benzamidine $(10 \mathrm{ml} / \mathrm{g}$ wet brain weight). Crude homogenates were then centrifuged at $600 \times g$ for $10 \mathrm{~min}$ to remove debris and nuclei. The resulting supernatant was then centrifuged at $45,000 \times g$ for $60 \mathrm{~min}$. This pellet was then resuspended in $2.5 \mathrm{ml}$ of ice-cold homogenization buffer per gram of brain used. Protein concentrations were determined using the BCA method (Pierce, Rockford, IL).

Immunoprecipitation. For immunoprecipitation of ankyrinB, spectrins, and 4.1 proteins, we used synaptosomes as the starting material. Samples were precleared with Protein A Tris-acryl (Pierce). Primary antibody was added overnight at $4^{\circ} \mathrm{C}$ and precipitated for $3 \mathrm{~h}$ at $4^{\circ} \mathrm{C}$ with Protein A Tris-acryl. Immunocomplexes were washed four times with IP buffer.

Isolation of detergent-resistant membranes. Detergent-resistant membranes were isolated by solubilizing optic nerve membrane homogenates in 1\% Triton X-100 (TX-100) lysis buffer (20 mm Tris-HCl, pH 8.0, 10 mм EDTA, $0.15 \mathrm{~m} \mathrm{NaCl}, 10 \mathrm{~mm}$ iodoacetamide, $0.5 \mathrm{~mm}$ PMSF, $10 \mathrm{~mm}$ sodium azide, and the same mixture of protease inhibitors as described above) at a concentration of $1 \mathrm{mg} / \mathrm{ml}$ protein for $1 \mathrm{~h}$ on a rotator at $4^{\circ} \mathrm{C}$. The resulting lysate was centrifuged at $13,000 \times g$ for 30 min to separate the soluble and insoluble fractions. Detergent-resistant membranes were resuspended to $1 \mathrm{ml}$ in lysis buffer (no TX-100). The pellet suspension was then mixed with $1 \mathrm{ml}$ of $2 \mathrm{M}$ sucrose. The resulting mixture was then overlaid with $2 \mathrm{ml}$ of $1 \mathrm{M}$ sucrose and $1.5 \mathrm{ml}$ of $0.2 \mathrm{M}$ sucrose. Samples were then centrifuged for $19 \mathrm{~h}$ at $192,000 \times g$, and $0.4 \mathrm{ml}$ fractions were then collected from the top of the tube. Sucrose and protein concentrations were measured for each fraction. Proteins were concentrated by overnight ethanol precipitation. The pellets were then resuspended in $100 \mu \mathrm{l}$ of reducing sample buffer, boiled, and analyzed by SDS-PAGE and immunoblotting.

SDS-PAGE and immunoblotting. Proteins were size fractionated by SDS-PAGE and analyzed by immunoblotting as described previously (Schafer et al., 2004). Polyacrylamide gels were silver stained using the SilverSnap silver staining kit (Pierce). For identification of proteins, gels were stained with Colloidal Blue Staining kit (Invitrogen). Ten gel pieces were then cut from the region corresponding to relative molecular weights of $100 \mathrm{kDa}$ or higher (see Fig. 1). These gel pieces were sent to the University of Connecticut Health Center Proteomics and Biological Mass Spectrometry Core for identification of proteins.

Neuronal cell culture. Hippocampal neurons were dissected and dissociated from embryonic day 18 rat embryos, plated on poly-D-lysine (Sigma, St. Louis, MO)/laminin (Invitrogen) coated glass coverslips at a density of 4800 cells $/ \mathrm{cm}^{2}$. Three hours after plating, the medium was changed from normal medium (10\% FBS in Neurobasal) to the maintaining medium [2\% B27 (Invitrogen), $0.5 \mathrm{~mm}$ L-glutamine, $25 \mu \mathrm{M}$ L-glutamate, and $1 \times$ antibiotic antimycotic solution (Sigma)]. Two days after plating, $1 \mu \mathrm{M}$ cytosine arabinoside (Sigma) was added to inhibit non-neuronal growth. Half of the medium was replaced with an equal volume of maintaining medium without glutamate every $4 \mathrm{~d}$. Hippocampal neurons were immunostained as described above.

Myelin retraction. Sciatic nerves were dissected and immediately immersed in rat Locke's solution (in $\mathrm{mm}$ ): $154 \mathrm{NaCl}, 5.6 \mathrm{KCl}, 2 \mathrm{CaCl}_{2}$, and 10 HEPES, pH 7.4. After removal of the epineural sheath, the nerves were immersed in collagenase $(3.6 \mathrm{mg} / \mathrm{ml})$ in rat Locke's solution for $20 \mathrm{~min}$. The nerve was then immersed in alternating hypotonic and hypertonic rat Locke's solution containing either $0.5 \mathrm{M}$ sucrose or diluted $1: 1$ in $\mathrm{ddH}_{2} \mathrm{O}$ for 5 min each (Chiu and Ritchie, 1980). Nerves were then teased on glass coverslips, air dried, and briefly fixed ( $5 \mathrm{~min}$ ) using $4 \%$ paraformaldehyde. In some cases, after myelin retraction, the teased nerve fibers were also treated with a $10 \mathrm{~min}$ acid strip using $0.1 \mathrm{M}$ glycine, $\mathrm{pH} 2.5$ before immunostaining.

\section{Results}

\section{Cofractionation of cytoskeletal and paranodal proteins}

To identify additional proteins that are associated with the paranodal axoglial junction, we used sucrose density centrifugation of detergent-insoluble membranes to isolate low-density paranodal junction protein-lipid complexes (Schafer et al., 2004). To further enrich our starting material for paranodal proteins and eliminate proteins derived from synapses (Hering et al., 2003), we used optic nerves, a pure white matter tract with a very high density of nodes and paranodes. These methods resulted in the purification of detergent-resistant membranes highly enriched in 


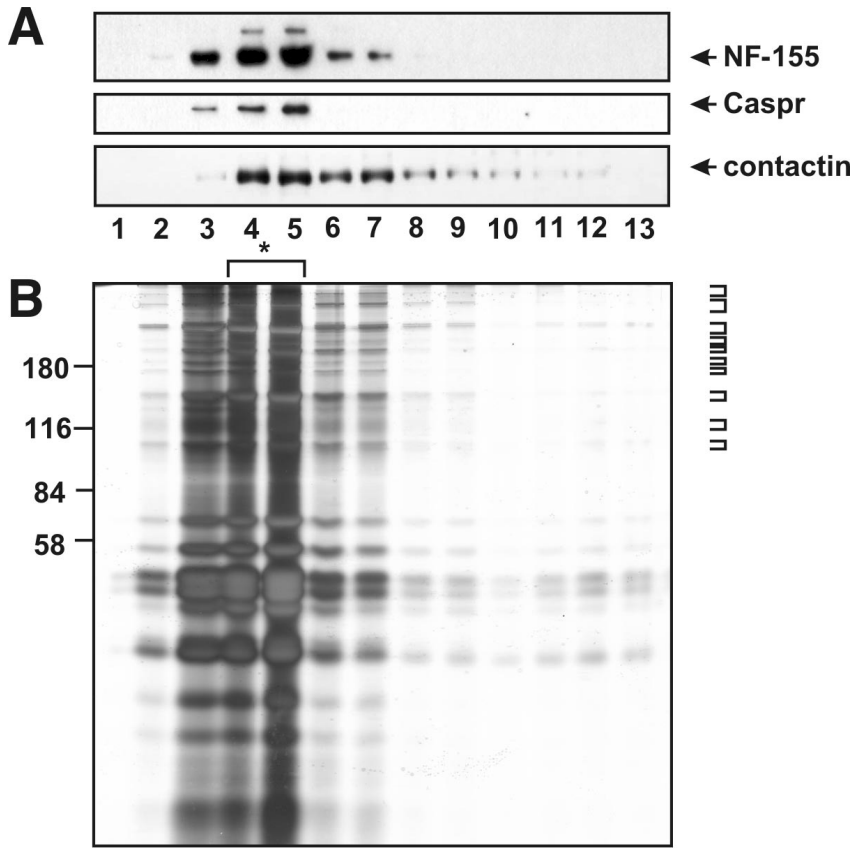

Figure 1. Isolation of detergent-resistant, low-density paranodal protein-lipid complexes. A, Sucrose density gradient analysis of the detergent-insoluble fraction from rat optic nerve membranes immunoblotted using pan NF (the band corresponding to NF-155 is indicated), Caspr, and contactin antibodies. The higher-molecular-weight band shown in the pan NF blot corresponds to NF-186, demonstrating the enrichment for paranodal proteins over nodal proteins. $\boldsymbol{B}$, Silver staining analysis of sucrose density gradient fractions from detergent-resistant optic nerve membranes. The silver-stained gel shows a complex mixture of proteins, most of which float in fractions $3-5$ on the gradient. For mass spectrometry, fractions 4 and 5 (asterisk) were pooled. Ten protein bands were cut and then analyzed by mass spectrometry (see brackets at the right of the gel).

NF-155, Caspr, and contactin (Fig. 1A, fractions 3-5). SDSPAGE of each sucrose gradient fraction revealed a complex mixture of proteins mainly in the low-density fractions (Fig. $1 B$ ). To identify these proteins, we pooled fractions 4 and 5 , separated the proteins by SDS-PAGE, and then excised 10 gel pieces corresponding to proteins with molecular weights of $110 \mathrm{kDa}$ and above (Fig. 1B). Proteins were then identified using liquid chromatography/tandem mass spectrometry.

We identified 51 proteins in the excised gel pieces. Although the optic nerve is less complex than brain, it still contains diverse cell types, including astrocytes, axons, and oligodendrocytes. Therefore, we did not expect that all identified proteins would be components of the paranodal junction. Nevertheless, we did find Caspr and contactin, with tryptic peptides covering 20 and 25\% of amino acids, respectively (Fig. 2 A). Among all identified proteins, the one with the highest amino acid coverage was $\alpha \mathrm{II}$ spectrin, with $47 \%$ coverage. $\beta$ II spectrin and ankyrinB (with 14 and $12 \%$ coverage, respectively), both of which are known to form a cytoskeletal protein complex with $\alpha$ II spectrin in other cells, were also identified (Bennett and Baines, 2001; Mohler et al., 2004). Using specific antibodies, we showed that $\alpha$ II spectrin, $\beta$ II spectrin, and ankyrinB cofractionate with Caspr in low-density detergent-insoluble membranes isolated from optic nerves (Fig. $2 B$ ). Because the protein 4.1 family of cytoskeletal anchoring proteins bind to the $\mathrm{N}$ terminus of $\beta$ spectrins and protein $4.1 \mathrm{~B}$ binds to Caspr (Gollan et al., 2002; Denisenko-Nehrbass et al., 2003), we also confirmed that protein $4.1 \mathrm{~B}$ cofractionates with Caspr and $\beta I I$ spectrin across the sucrose gradient (Fig. $2 \mathrm{~B}$ ). This is particularly important because protein $4.1 \mathrm{~B}$ family of cytoskel-

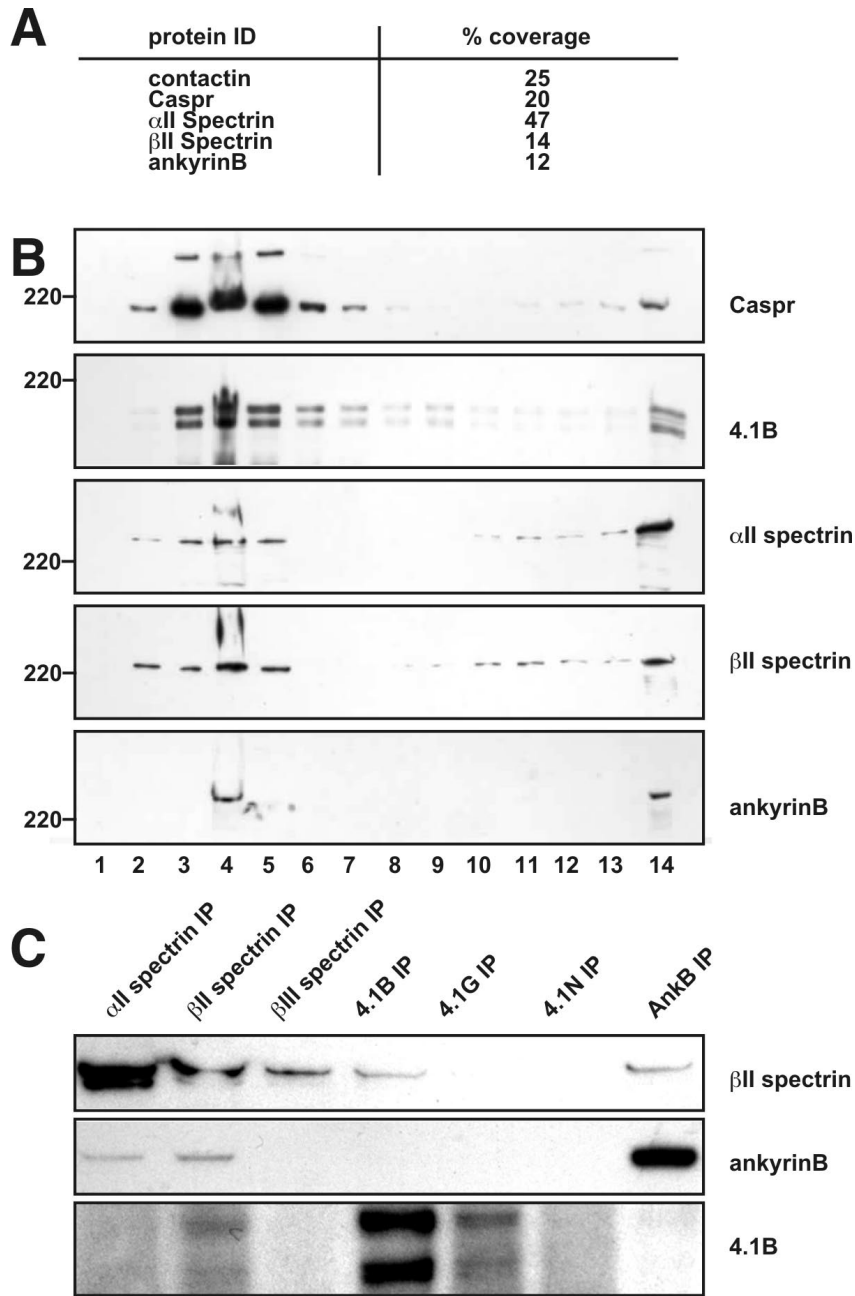

Figure 2. Cofractionation of paranodal and cytoskeletal proteins in detergent-resistant, low-density protein-lipid complexes isolated from rat optic nerves. $\boldsymbol{A}$, Five proteins identified by mass spectrometry of proteins isolated from optic nerve lipid rafts. Percentage coverage indicates the percentage of the protein sequence covered by the identified tryptic peptides. $\boldsymbol{B}$, Immunoblots showing that cytoskeletal proteins are detected in low-density fractions from sucrose gradient centrifugation of detergent-insoluble optic nerve membranes. Numbers on the bottom represent the fraction number collected, and fraction 14 corresponds to the pellet at the bottom of the gradient. C, Association of $\alpha$ ll spectrin, $\beta \|$ spectrin, protein 4.1B, and ankyrinB in mouse brain. Solubilized mouse brain membranes were subjected to immunoprecipitation to the various cytoskeletal proteins as indicated across the top. Immunoblots were performed with antibodies to $\beta \|$ spectrin, protein $4.1 \mathrm{~B}$, and ankyrinB as indicated on the right of each panel.

etal proteins binds to both Caspr and $\beta$ II spectrin. Immunoprecipitation of spectrins $(\alpha \mathrm{II}, \beta \mathrm{II}$, and $\beta \mathrm{III}), 4.1$ proteins $(4.1 \mathrm{~B}$, $4.1 \mathrm{G}$, and $4.1 \mathrm{~N})$, and ankyrinB showed that $\alpha \mathrm{II}$ spectrin, ankyrinB, and $4.1 \mathrm{~B}$ each coimmunoprecipitated $\beta \mathrm{II}$ spectrin from rat brain lysates (Fig. $2 C$ ). These results indicate that a cytoskeletal protein complex consisting of $\alpha \mathrm{II}$ spectrin, $\beta \mathrm{II}$ spectrin, ankyrinB, and protein $4.1 \mathrm{~B}$ exists in brain, and these proteins cofractionate with Caspr, contactin, and NF-155 in low-density detergent-resistant membranes isolated from optic nerves.

\section{Cytoskeletal proteins are enriched at paranodal junctions in the CNS and PNS}

To determine whether any of the cytoskeletal proteins identified above are located at paranodal junction, we immunostained optic and sciatic nerve sections for $\alpha$ II spectrin, $\beta$ II spectrin, and 


\section{Optic Nerve (CNS)}
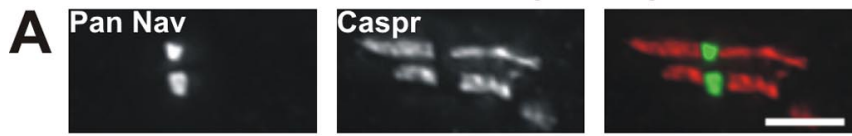

B

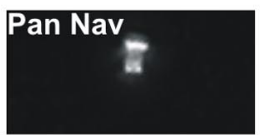

C

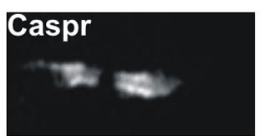

D

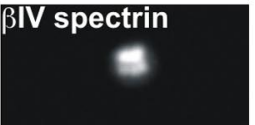

E
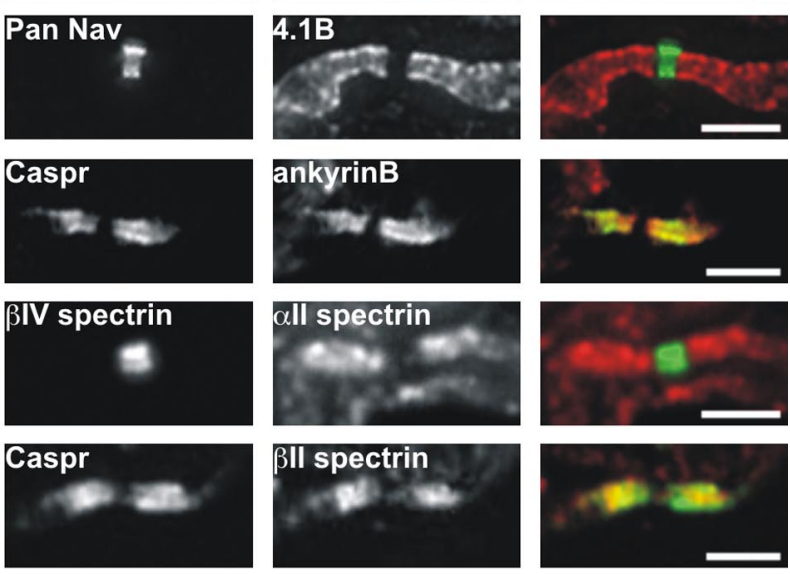

Sciatic Nerve (PNS)
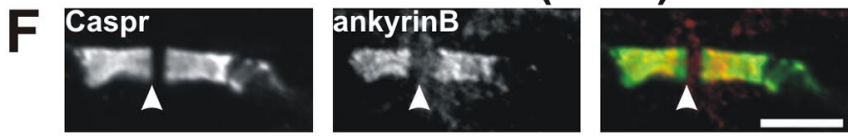

G
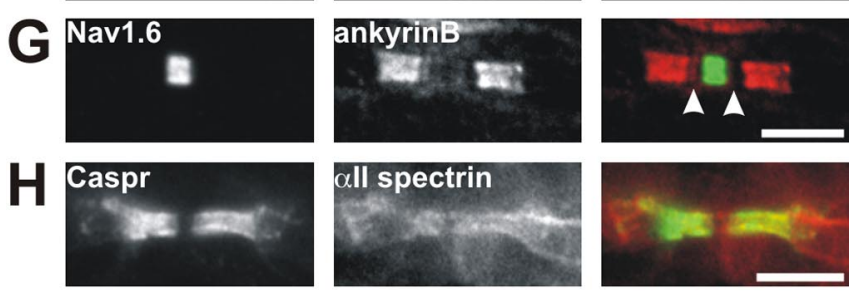

I

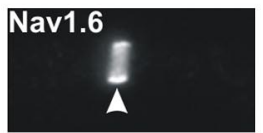

$\mathbf{J}$

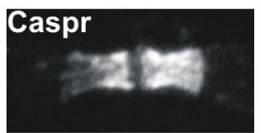

K
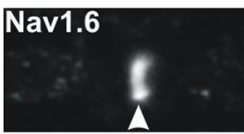

$\mathbf{L}$

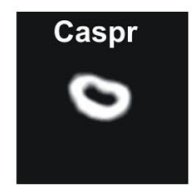

M

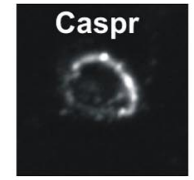

$\mathbf{N}$

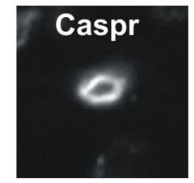

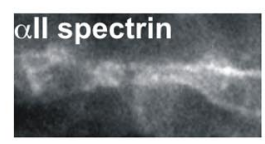
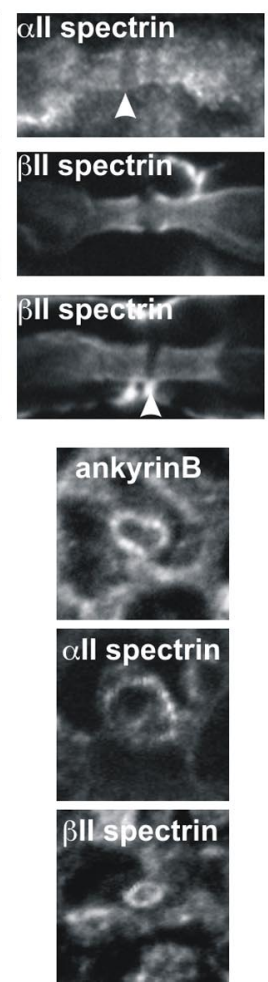
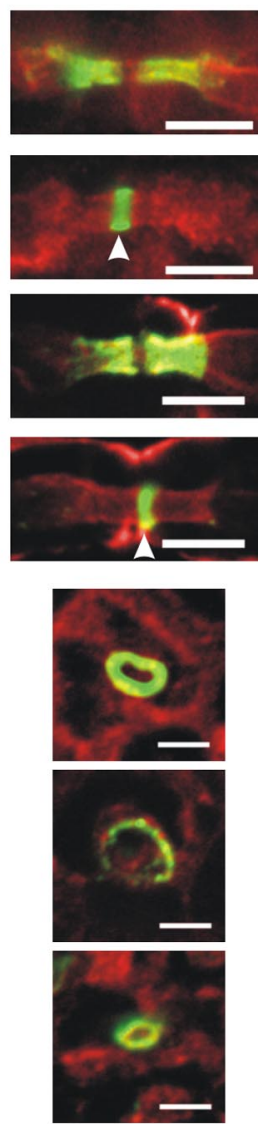

Figure 3. Cytoskeletal proteins are localized to paranodal junctions in the optic and sciatic nerves. Longitudinal sections of optic $(\boldsymbol{A}-\boldsymbol{E})$ and sciatic $(\boldsymbol{F}-\boldsymbol{K})$ nerves or cross sections of sciatic nerve $(\boldsymbol{L}-\boldsymbol{N})$ were labeled with the antibodies indicated in each panel. The merged images are shown on the right. $\boldsymbol{A}$, Pan Nav (green) and Caspr (red). B, Pan Nav (green) and protein 4.1B

ankyrinB. Immunostaining of optic nerve with antibodies against Nav channels and Caspr or protein $4.1 \mathrm{~B}$ shows that these proteins flank nodes of Ranvier (Fig. $3 A, B$ ). Whereas Caspr is located only at paranodal junctions (Fig. $3 A$ ), protein $4.1 \mathrm{~B}$ extends into juxtaparanodal domains in which it interacts with Caspr2 (Fig. $3 B$ ) (Poliak et al., 2001; Denisenko-Nehrbass et al., 2003). Double labeling for ankyrinB (Fig. 3C), $\alpha$ II spectrin (Fig. 3D), and $\beta I I$ spectrin (Fig. 3E) shows that these proteins are highly enriched in paranodal junctions, colocalize with Caspr (Fig. 3C,E), and flank nodal $\beta I V$ spectrin (Fig. 3D). Besides being enriched at paranodal junctions, there was also some diffuse staining for each of these cytoskeletal proteins throughout optic nerve axons (data not shown).

Immunostaining of sciatic nerve revealed that ankyrinB, $\alpha \mathrm{II}$ spectrin, and $\beta$ II spectrin are all located at paranodal junctions in the PNS (Fig. $3 F-K$ ). AnkyrinB immunoreactivity was readily detected at paranodal junctions and appeared "nested" within Caspr immunoreactivity (Fig. $3 F$ ). The Caspr immunostaining also extended further toward the node than ankyrinB staining (Fig. $3 F$, arrowhead), resulting in a clear gap between paranodal ankyrinB and nodal Nav1.6 (Fig. 3G, arrowheads); the significance of this difference in localization is unknown, but the lack of complete colocalization suggests that these proteins may not directly interact (see below).

In contrast to ankyrinB, immunostaining in the sciatic nerve for $\alpha$ II spectrin (Fig. $3 H, I$ ) and $\beta$ II spectrin (Fig. $3 J, K$ ) was more diffuse and less restricted to the paranodal junction. Paranodal immunoreactivity was clearly detected, but $\alpha$ II spectrin and $\beta \mathrm{II}$ spectrin immunostaining also extended into juxtaparanodal domains (Fig. $3 H-J$ ). As in the optic nerve, both $\alpha$ II spectrin and $\beta I I$ spectrin were excluded from nodes, resulting in a clear gap in immunofluorescence (Fig. $3 \mathrm{I}, \mathrm{K}$, arrowheads). Both $\alpha \mathrm{II}$ and $\beta \mathrm{II}$ spectrin were also detected at very high levels in Schwann cells (data not shown), making it sometimes difficult to distinguish paranodal immunoreactivity. Therefore, we double-stained cross sections of sciatic nerve using antibodies against Caspr to mark the paranodal junction and ankyrinB, $\alpha$ II spectrin, or $\beta$ II spectrin. We found that each of these cytoskeletal proteins was present in a ring of immunoreactivity that colocalized with Caspr immunostaining (Fig. $3 L-N$ ). These results show that ankyrinB, $\alpha \mathrm{II}$ spectrin, and $\beta$ II spectrin are found at paranodal junctions in the CNS and PNS and comprise a specialized paranodal cytoskeleton analogous to the specialized cytoskeleton found at nodes of Ranvier.

The paranodal cytoskeleton remains intact after myelin retraction

Because $\alpha \mathrm{II}$ spectrin, $\beta \mathrm{II}$ spectrin, ankyrinB, and protein $4.1 \mathrm{~B}$ all form a complex in brain and protein $4.1 \mathrm{~B}$ binds to Caspr in the axon, this paranodal cytoskeletal protein complex is most likely axonal. Nevertheless, it is also possible that one (or more) of the paranodal cytoskeletal proteins we identified might also be present in the myelinating cell. Therefore, we treated unfixed sciatic nerve axons with collagenase, followed by alternating hy-

(red). C, Caspr (green) and ankyrinB (red). D, $\beta$ IV spectrin (green) and $\alpha$ ll spectrin (red). $\boldsymbol{E}$, Caspr (green) and $\beta \| l$ spectrin (red). $\boldsymbol{F}-\boldsymbol{K}$, Sciatic nerve. $\boldsymbol{F}$, Caspr (green) and ankyrinB (red). G, Nav1.6 (green) and ankyrinB (red). $\boldsymbol{H}$, Caspr (green) and $\alpha \| l$ spectrin (red). $\boldsymbol{I}$, Nav1.6 (green) and $\alpha \| l$ spectrin (red). J, Caspr (green) and $\beta \|$ spectrin (red). $\boldsymbol{K}$, Nav1.6 (green) and $\beta \|$ spectrin (red). L, Caspr (green) and ankyrinB (red). $\boldsymbol{M}$, Caspr (green) and $\alpha$ ll spectrin. $\boldsymbol{N}$, Caspr (green) and $\beta \| l$ spectrin. Scale bars: $\boldsymbol{A}-\boldsymbol{E}, \boldsymbol{L}-\boldsymbol{N}, 3 \mu \mathrm{m} ; \boldsymbol{F}-\boldsymbol{K}, 5 \mu \mathrm{m}$. 
potonic and hypertonic solutions to cause retraction of the Schwann cell away from the paranodal junction (Chiu and Ritchie, 1980). We immunostained these treated nerves using antibodies against $\beta$ IV spectrin, MBP, ankyrinB (Fig. $4 A, B$ ), $\beta$ II spectrin (Fig. $4 C$ ), or pan NF. We found that enzyme treatment resulted in marked retraction of the myelin sheath (Fig. 4A-C, arrows), exposing a long region of bare axon around the node of Ranvier. Enzymatic retraction did not affect staining for axonal $\beta I V$ spectrin (asterisk). We found that, in the treated nerve fibers, immunoreactivity for ankyrinB (Fig. $4 A$, arrowheads, $B$ ) and $\beta$ II spectrin (Fig. $4 C$ ) remained flanking nodes of Ranvier. Despite the retraction of myelin membranes away from nodes, paranodal immunoreactivity for neurofascin was retained, most likely attributable to very strong interactions between the axonal and glial CAMs (Fig. 4D, arrowheads). Therefore, to exclude the possibility that ankyrinB might bind to paranodal NF-155, after myelin retraction, we performed an acid strip of the axon to disrupt NF-155 binding to axonal CAMs. This extra step eliminated paranodal pan NF immunostaining but did not affect paranodal ankyrinB staining (Fig. 4E). Together, these results suggest that ankyrinB and $\beta$ II spectrin are axonal components of the paranodal junction.

$\alpha$ II spectrin, $\beta$ II spectrin, and ankyrinB accumulate at paranodal junctions during their formation

Paranodes form during early CNS and PNS myelination. It is possible that the paranodal cytoskeleton forms after Caspr and contactin accumulate and that these axonal CAMs are retained and stabilized through interactions with both glial NF155 and the axonal paranodal cytoskeleton. Alternatively, the paranodal cytoskeleton may form before the clustering of Caspr and contactin, providing a nucleation site for the establishment of paranodal junctions in locations defined by the neuron. To distinguish between these possibilities, we immunostained developing optic nerve using antibodies against $\mathrm{Nav}$ channels (pan Nav) and $\beta$ II spectrin, or pan $\mathrm{Nav}$ and protein $4.1 \mathrm{~B}$ (Fig. 5A). At postnatal day 5 (P5), we did not detect any accumulation of $\beta$ II spectrin or protein 4.1B. The first time at which we were able to detect a specialized paranodal cytoskeleton was at P11, several days after paranodal junctions begin to form (P8) (Rasband et al., 1999). At this time, we clearly detected an enrichment of $\beta$ II spectrin (Fig. $5 A$, inset) and protein $4.1 \mathrm{~B}$ at paran-
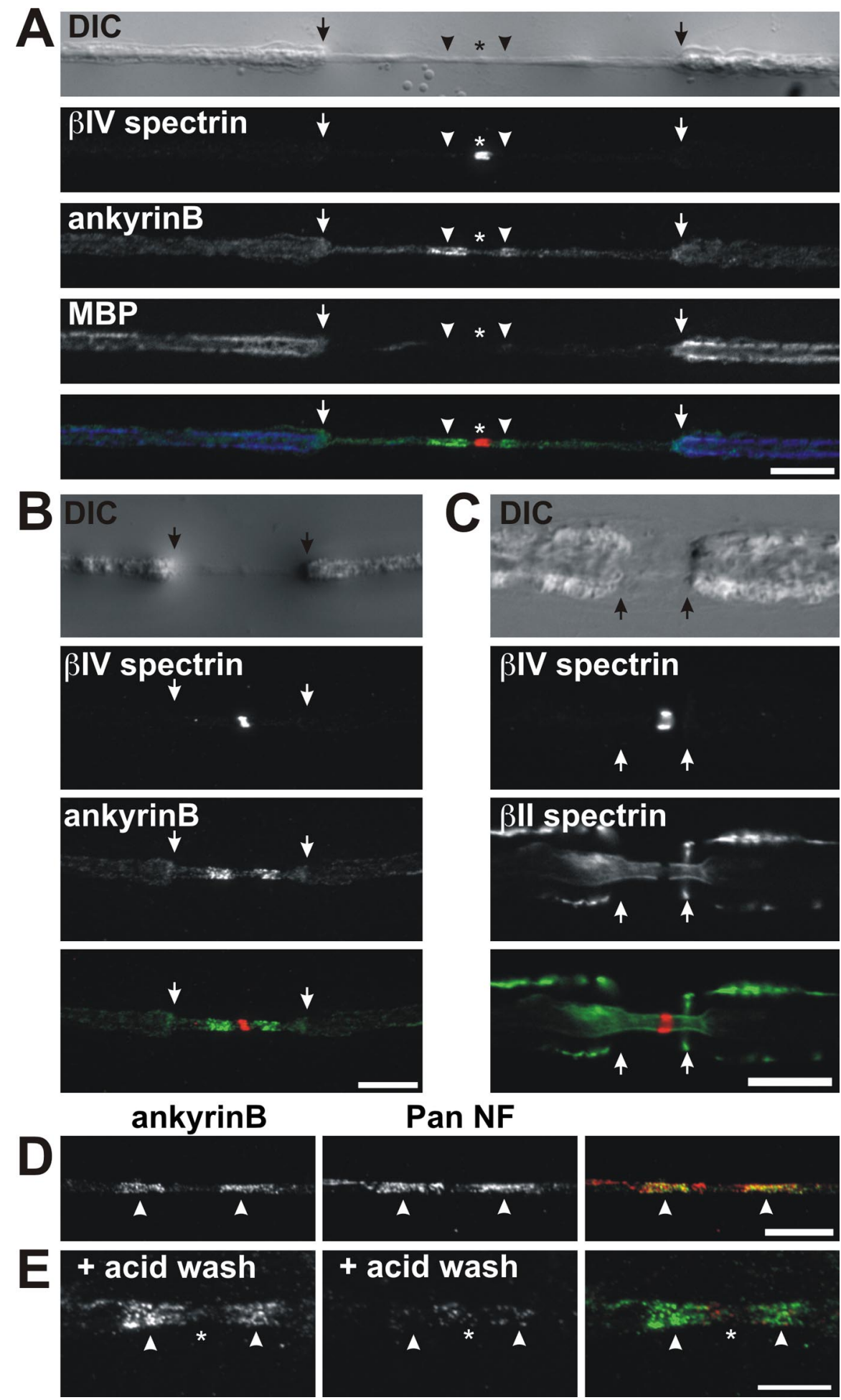

Figure 4. Retraction of myelin membranes does not alter the paranodal junction localization of ankyrinB or $\beta \|$ spectrin. $\boldsymbol{A}, \boldsymbol{B}$, Sciatic nerve fibers that were treated with collagenase to cause myelin retraction. The nerve fiber is shown using differential interference contrast (DIC). Immunolabeling for $\beta$ IV spectrin (red), ankyrinB (green), and MBP (blue; only in $\boldsymbol{A}$ ) is shown as indicated. C, Collagenase-treated nerve fiber immunostained using antibodies against $\beta I V$ spectrin (red) and $\beta \| l$ spectrin (green). D, Paranodal ankyrinB (green) and paranodal pan NF (red) immunoreactivity is retained after myelin retraction. $\boldsymbol{E}$, Acid stripping of nerve fibers after myelin retraction eliminates paranodal pan NF (red) staining but does not affect paranodal ankyrinB (green) immunoreactivity. Arrows indicate the edge of the retracted myelin. Arrowheads indicate paranodal junctions. Asterisks indicate nodes of Ranvier. Scale bars: $A-D, 10 \mu \mathrm{m} ; E, 5 \mu \mathrm{m}$. 


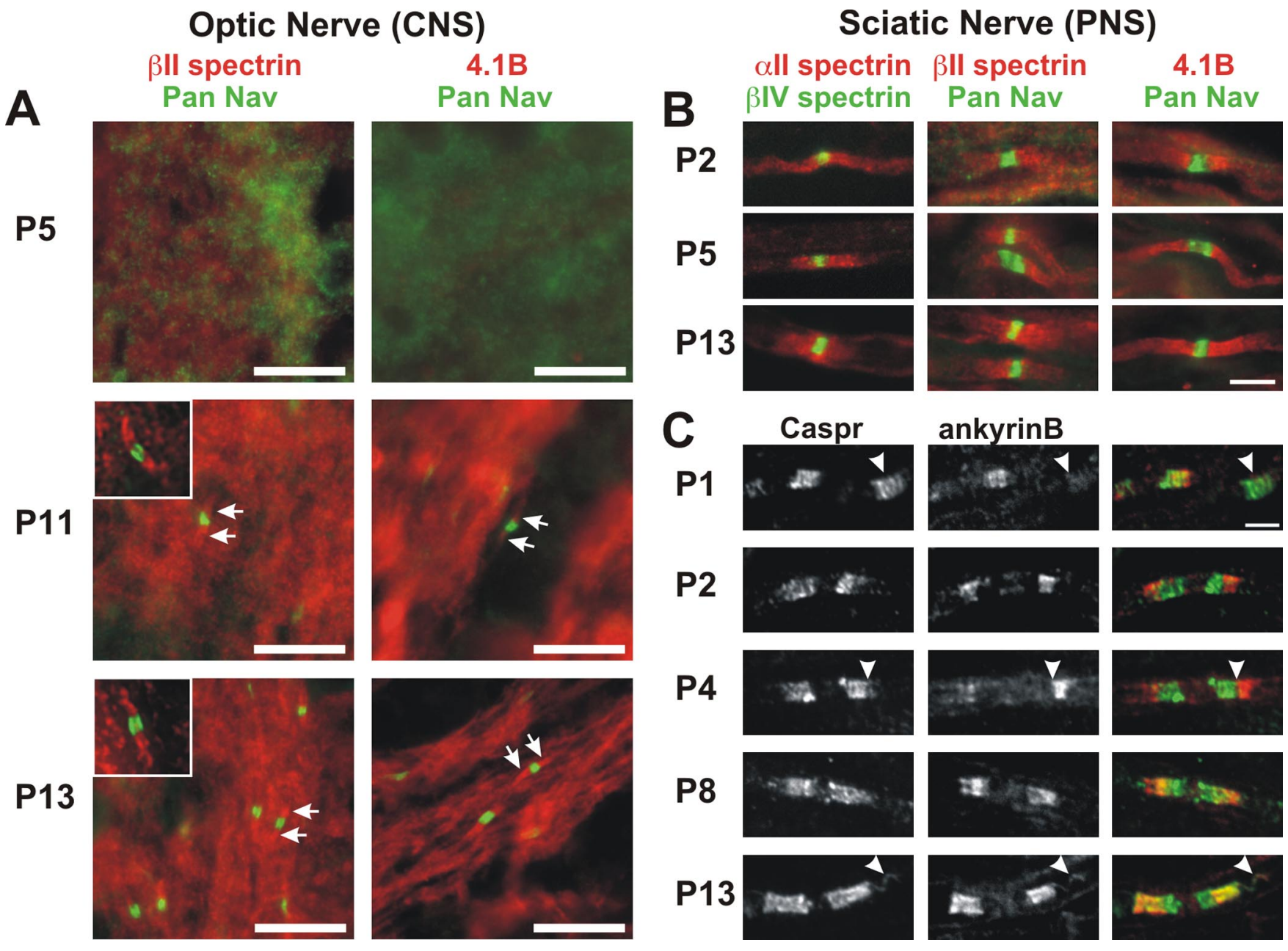

Figure 5. Cytoskeletal proteins localize to paranodal junctions during paranode formation. $A$, Double immunostaining of rat optic nerve at $P 5$, P11, and P13 using antibodies against pan Nav (green) and $\beta \| l$ spectrin (red) or protein 4.1B (red). Inset shows detail of individual nodes and paranodes labeled for pan Nav and $\beta \| l$ spectrin. $B$, Double immunostaining of rat sciatic nerve at P2, P5, and P13 using antibodies against $\beta$ IV spectrin (green) and $\alpha$ ll spectrin, pan Nav (green) and $\beta \| l$ spectrin (red), or pan Nav (green) and protein 4.1B (red). C, Caspr (green) and ankyrinB (red) immunostaining of sciatic nerve paranodes during developmental myelination at P1, P2, P4, P8, and P13. Scale bars: $A, B, 10 \mu \mathrm{m} ; C, 3 \mu \mathrm{m}$.

odes. By P13, most developing paranodes had detectable $\beta \mathrm{II}$ spectrin and protein $4.1 \mathrm{~B}$ (Fig. $5 A$ ).

In the sciatic nerve, paranodes begin to form as early as P0-P1 (Rios et al., 2000; Schafer et al., 2006). We found that, at approximately P2, the cytoskeletal proteins $\alpha$ II spectrin, $\beta$ II spectrin, and protein $4.1 \mathrm{~B}$ began to accumulate at sites flanking nodal clusters of $\beta \mathrm{IV}$ spectrin or Nav channels (Fig. 5B). Paranodal immunoreactivity for these cytoskeletal proteins increased during peripheral myelination (Fig. $5 B$ ). At all time points, we found instances of immunoreactivity at paranodal junctions (Fig. $5 B$, P5 $\alpha$ II spectrin) and immunoreactivity that extended into juxtaparanodal and even internodal domains (Fig. 5B, P2 $\alpha$ II spectrin or $\mathrm{P} 13$ protein $4.1 \mathrm{~B}$ ). Thus, in the optic and sciatic nerves, $\alpha \mathrm{II}$ and $\beta$ II spectrin accumulate at paranodal junctions after the clustering of the CAMs Caspr and NF-155.

In contrast to $\alpha \mathrm{II}$ and $\beta \mathrm{II}$ spectrin, we found that ankyrinB was spatially more restricted during myelination (Fig. 5C). Like $\alpha \mathrm{II}$ spectrin and $\beta \mathrm{II}$ spectrin, ankyrinB was detected after the accumulation of Caspr (Fig. 5C, P1, arrowhead). Much to our surprise, we found that, when ankyrinB was first detected (P1P2), it only partially colocalized with Caspr at the edge of the paranodal junction, where the transition from the paranode to the juxtaparanode occurs (Fig. 5C, P2, P4, arrowhead). These results suggest that neither Caspr nor NF-155 directly interact with ankyrinB, because they do not colocalize during development. Thus, localization of ankyrinB may depend on another, as yet unknown, axonal membrane protein.

As myelination progressed, the location of ankyrinB shifted toward the paranode so that ankyrinB immunoreactivity overlapped more with that of Caspr (Fig. 5C, P8). Finally, by $\sim 2$ weeks after birth, most ankyrinB immunoreactivity colocalized with Caspr immunostaining, although as in the adult, it appeared to be nested within the Caspr staining, and a distinct gap remained between the node of Ranvier and the start of the detectable ankyrinB. In some cases, we could detect colocalization between Caspr and ankyrinB along the inner mesaxon (Fig. 5C, P13, arrowhead) (Arroyo et al., 2001). Together, these results show that ankyrinB accumulates at paranodal junctions after the accumulation of the CAMs Caspr and NF-155.

\section{The localization of ankyrinB at paranodes requires an intact} paranodal junction

To investigate the mechanisms regulating formation and/or maintenance of the paranodal cytoskeleton, we examined the localization of ankyrinB and $\beta$ II spectrin in sciatic nerves from mice lacking Caspr $\left(\mathrm{Caspr}^{-/-}\right)$and Caspr2 $\left(\mathrm{Caspr}^{-/-}\right)$. Caspr $^{-1-}$ mice fail to form transverse bands and proper paranodal junctions; in many cases, paranodal loops evert from the 
axolemma (Bhat et al., 2001; Gollan et al., 2003). As shown in Figure 6, Caspr and ankyrinB are both located at paranodes in wild-type (WT) mouse sciatic nerve (225 of 230 nodes), whereas Caspr2 and ankyrinB are located in adjacent but mutually exclusive domains. Fluorescence intensity profiles along the axon show distinct peaks corresponding to paranodes and juxtaparanodes (Fig. 6Aa,Ba). In contrast, ankyrinB could not be detected at most paranodes of $\mathrm{Caspr}^{-/-}$mice (97 of 102 nodes) (Fig. 6Ab). Occasionally, low levels of ankyrinB immunoreactivity are associated with paranodes ( 5 of 102 nodes) (Fig. 6Bb). However, it was necessary to significantly increase camera exposure times to detect this ankyrinB immunoreactivity. This also resulted in an increase in fluorescence along the surface of the myelin sheath and around the nodal gap, some of which corresponds to the single peak observed in the Caspr ${ }^{-1-}$ fluorescence intensity profiles (Fig. $6 A b, B b$ ).

If the paranodal cytoskeleton is established through interactions between Caspr and protein $4.1 \mathrm{~B}$, a normal paranodal $\mathrm{cy}$ toskeleton might exist in $\mathrm{Caspr}^{-1-}$ mice because Caspr2 is located at paranodes in these mice (Fig. $6 \mathrm{Bb}$ ) and can also bind to protein 4.1B. However, ankyrinB fails to localize to most paranodal junctions; double immunostaining for Caspr2 and ankyrinB revealed only a few instances of weak paranodal ankyrinB immunoreactivity (Fig. $6 \mathrm{Bb}$ ). In contrast, $\beta \mathrm{II}$ spectrin localization in $\mathrm{Caspr}^{-/-}$and $\mathrm{Caspr}^{-/-}$mice is indistinguishable from WT mice (supplemental Fig. S1, available at www.jneurosci.org as supplemental material), suggesting that protein $4.1 \mathrm{~B}$ may be more important for $\beta$ II spectrin localization than for ankyrinB localization. Finally, both Caspr and ankyrinB are clustered at high densities at paranodes of Caspr $2^{-/-}$mice (Fig. $6 A c, B c$ ). Fluorescence intensity profiles show two peaks of fluorescence corresponding to each paranodal junction (Fig. $6 A c, B c$; in $B c$, the very strong horizontal band of ankyrinB immunoreactivity corresponds to unmyelinated axons). Together, these results indicate that formation and/or maintenance of a paranodal cytoskeleton that includes ankyrinB depends on paranodal axon-glia interactions.

\section{$\beta \mathrm{II}$ spectrin is excluded from nodes of Ranvier in $\beta \mathrm{IV}$ spectrin mutant mice}

As shown above, there is a pronounced gap in $\beta$ II spectrin immunoreactivity precisely at the node of Ranvier (Fig. $3 \mathrm{~J}, \mathrm{~K}$ ), and $\beta$ II spectrin localization was normal in sciatic nerves of Caspr ${ }^{-1-}$ mice. Therefore, we considered the possibility that $\beta$ II spectrin localization may be intrinsically determined, perhaps by other components of the axonal cytoskeleton (e.g., nodal $\beta$ IV spectrin) rather than paranodal neuron-glia interactions. To test this possibility, we examined the localization of $\beta$ II spectrin in primary hippocampal neuron cultures lacking neuron-glia interactions. In these neurons, $\beta \mathrm{IV}$ spectrin and Nav channels are clustered in very high densities at the axon initial segment (AIS) (Fig. 7 $A, B$, respectively). When we immunostained neurons with antibodies against $\beta$ II spectrin, we found that it was highly enriched in axons (arrowheads). However, at the AIS, $\beta$ II spectrin immunoreactiv-

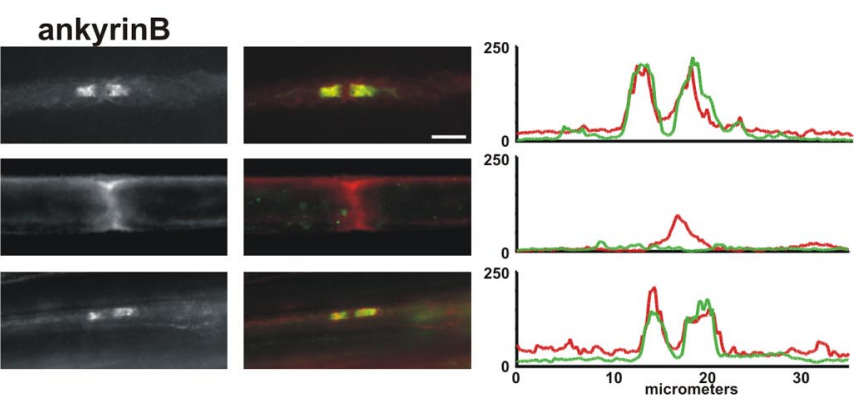

ankyrinB
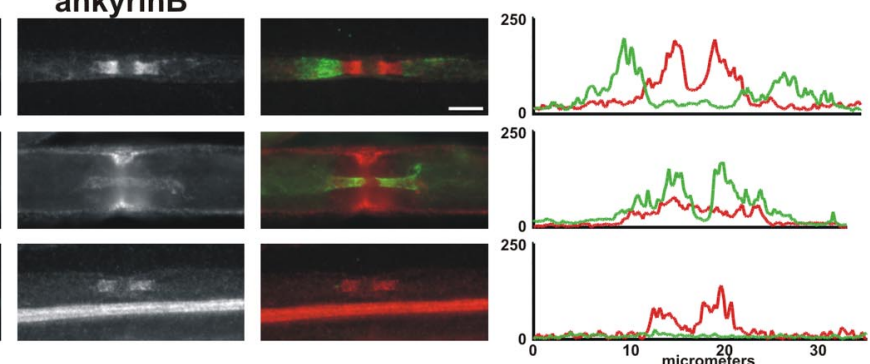

mice. $\boldsymbol{A}$, Caspr (green) and ankyrinB (red) immunostaining of sciatic nerve. Aa, WT mouse sciatic nerve. Ab, Caspr ${ }^{-1-}$ mouse sciatic nerve. Ac, Caspr $2^{-1-}$ mouse sciatic nerve. B, Caspr2 (green) and ankyrinB (red) immunostaining of mouse sciatic nerve. Ba, WT mouse sciatic nerve. $\boldsymbol{B} \boldsymbol{b}$, $\mathbf{C a s p r}^{-1-}$ mouse sciatic nerve. $\boldsymbol{B} \boldsymbol{c}$, Caspr $2^{-1-}$ mouse sciatic nerve. Fluorescence intensity profiles were generated by measuring fluorescence intensity along a $35-\mu \mathrm{m}$-long line drawn through the juxtaparanodes, paranodes, and node. Scale bars, $5 \mu \mathrm{m}$.

ity was significantly decreased compared with the rest of the axon. Fluorescence intensity profiles along the axon showed the decrease in $\beta$ II spectrin fluorescence intensity occurred exactly where there was an increase in $\beta$ IV spectrin or pan Nav immunoreactivity at the AIS (Fig. $7 A, B$ ). Thus, even in hippocampal neurons without any extrinsic influence from myelinating glial cells, $\beta$ II and $\beta$ IV spectrin occupy mutually exclusive domains.

To test whether $\beta$ IV spectrin alone influences the localization of $\beta$ II spectrin, we examined $\beta$ II spectrin localization at nodes of Ranvier in $q v^{3 J}$ mutant mice. These mice have a mutation in the $\beta \mathrm{IV}$ spectrin gene resulting in the premature truncation of the protein (Parkinson et al., 2001). This mutation causes loss of $\beta I V$ spectrin from CNS nodes, nodal membrane protrusions, and significantly longer nodal Nav channel clusters (Fig. 7C) (Yang et al., 2004). Nevertheless, $\beta$ II spectrin was still excluded from CNS nodes in $q v^{3 J}$ mice (Fig. $7 C$, arrowheads). AnkyrinB localization was also unaffected by the mutation (data not shown). PNS nodes of Ranvier in $q v^{3 J}$ mice are mostly normal, despite dramatically reduced or no $\beta I V$ spectrin (Yang et al., 2004). Immunostaining for $\beta$ II spectrin and ankyrinB showed that these proteins were normally excluded from PNS nodes of Ranvier in $q v^{3 J}$ mice (data not shown). Thus, in the absence of $\beta$ IV spectrin, $\beta$ II spectrin and ankyrinB are normally located at paranodal junctions, and $\beta I V$ spectrin is not required for the exclusion of $\beta$ II spectrin from nodes of Ranvier.

\section{Discussion}

A specialized cytoskeleton is important for the formation of polarized domains in many cell types. The complexity of ankyrin and spectrin gene families (including alternative mRNA splicing) accommodates this membrane compartmentalization (Bloch and Morrow, 1989; Malchiodi-Albedi et al., 1993; Stankewich et al., 1998; Berghs et al., 2000; Bennett and Baines, 2001). For example, in epithelial cells, ankyrinG is located at lateral membranes and is essential for both lateral membrane biogenesis and maintenance of polarity (Kizhatil and Bennett, 2004). In neu- 


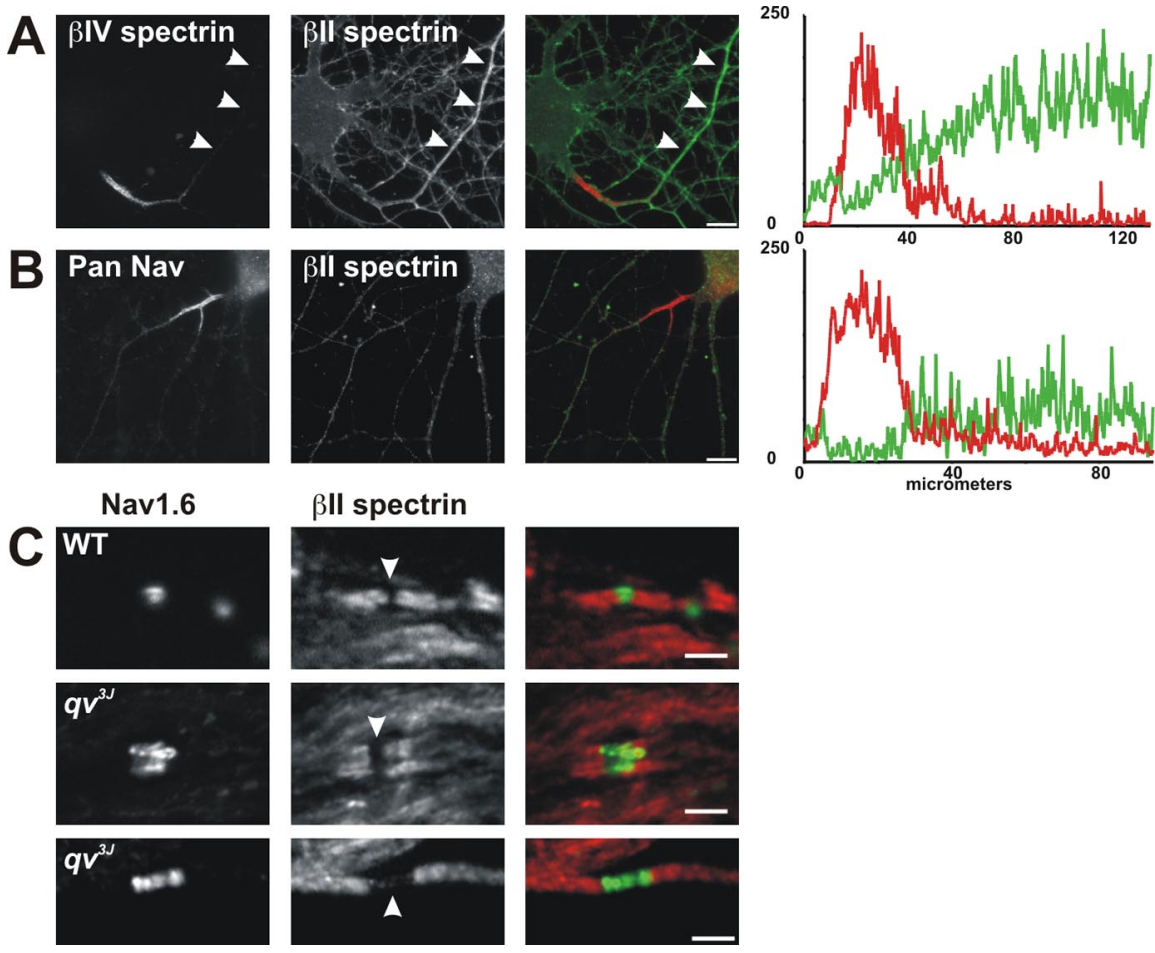

Figure 7. Disruption of the nodal cytoskeleton does not alter localization of $\beta \| l$ spectrin or ankyrinB. A, Cultured hippocampal neurons immunostained for $\beta I V$ spectrin (red) and $\beta \| l$ spectrin (green). $\beta I V$ spectrin labels the axon initial segment, whereas $\beta \|$ spectrin labels the axon (arrowheads). $\boldsymbol{B}$, Cultured hippocampal neurons immunostained for pan Nav (red) and $\beta \| l$ spectrin (green). Fluorescence intensity profiles in $\boldsymbol{A}$ and $\boldsymbol{B}$ show a reduction in $\beta \|$ immunoreactivity at the axon initial segment. $\boldsymbol{C}, \boldsymbol{D}, \mathrm{WT}$ and $q v^{3 J}$ optic nerves $(\boldsymbol{C})$ immunostained for Nav1.6 (green) and $\beta \|$ spectrin (red). Arrowheads show the nodal gap in $\beta \|$ spectrin immunostaining. Scale bars: $A, B, 10 \mu \mathrm{m} ; \boldsymbol{C}, 3 \mu \mathrm{m}$.

rons, ankyrinG and $\beta \mathrm{IV}$ spectrin are both required for Nav channel clustering at axon initial segments (Zhou et al., 1998; Komada and Soriano, 2002). This very same complex, including specific splice variants of $\beta$ IV spectrin, is also important for Nav channel localization and membrane stability at nodes of Ranvier (Berghs et al., 2000; Lacas-Gervais et al., 2004; Yang et al., 2004). In each case, the cytoskeleton is important for the localization and/or retention of various membrane proteins, including ion channels and CAMs (schematically shown in supplemental Figure S2, node, available at www.jneurosci.org as supplemental material). In the results presented here, we have shown that another highly specialized cytoskeletal protein complex is found immediately adjacent to nodes of Ranvier at paranodal junctions. By analogy with other polarized cell types using ankyrins, spectrins, 4.1 proteins, and CAMs, we propose that the paranodal cytoskeleton is responsible for the stabilization of paranodal transcellular protein complexes and the mechanical stability of the axoglial apparatus.

\section{The paranodal cytoskeleton: axonal or glial?}

AnkyrinB, $\alpha$ II spectrin, and $\beta$ II spectrin are all enriched at paranodal junctions in the CNS and PNS. Although at present we cannot exclude the possibility that these molecules are also found in the glial paranodes, several lines of evidence suggest that the cytoskeletal proteins identified here are axonal. First, retraction of the myelin sheath does not alter the paranodal localization of ankyrinB or $\beta$ II spectrin. Second, a macromolecular protein complex consisting of ankryinB, $\alpha$ II spectrin, $\beta$ II spectrin, and protein $4.1 \mathrm{~B}$ can be immunoprecipitated from rat brain. Because protein $4.1 \mathrm{~B}$ is located in axons at paranodes and juxtaparanodes where it interacts with the axonal membrane proteins Caspr and Caspr2, respectively (Gollan et al., 2002; DenisenkoNehrbass et al., 2003), ankyrinB, $\alpha$ II spectrin, and $\beta$ II spectrin are most likely also located in the axon. Third, although ankyrinB can bind to NF-155 (Davis and Bennett, 1994), this interaction is blocked by phosphorylation of a cytoplasmic tyrosine found in both NF-155 and NF-186 (Tuvia et al., 1997). In contrast to nodal NF-186, paranodal NF-155 is phosphorylated and cannot bind to ankyrinB (Jenkins et al., 2001). Consistent with this idea, we were unable to coimmunoprecipitate NF-155 and ankyrinB (data not shown). Together, these arguments suggest that the paranodal cytoskeletal proteins identified here are axonal. However, definitive proof will require high-resolution immunoelectron microscopy or tissue-specific knockdown of each cytoskeletal protein because mice deficient for $\beta$ II spectrin and ankyrinB are embryonic and perinatal lethal, respectively (Scotland et al., 1998; Tang et al., 2003).

\section{The paranodal protein complex}

How do ankyrinB, $\alpha$ II spectrin, and $\beta I I$ spectrin interact with known paranodal proteins to stabilize axoglial junctions? As depicted in supplemental Figure S2 (available at www.jneurosci.org as supplemental material), there are three known paranodal CAMs: glial NF-155, axonal Caspr, and axonal contactin. These latter two proteins form a heterodimer that may interact directly with NF-155 (Charles et al., 2002). However, other data suggest that NF-155 binds only to contactin and that Caspr inhibits their interaction (Gollan et al., 2003). Whatever the details of the complex, Caspr is necessary to link to the cytoskeleton because contactin has a glycosylphosphatidylinositol membrane anchor and no cytoplasmic domain. In agreement, a mutant of Caspr lacking its intracellular domain was not retained properly on the axolemma at the paranodal junction (Gollan et al., 2002). Caspr interacts with protein 4.1B (Gollan et al., 2002; Denisenko-Nehrbass et al. 2003), and 4.1 family members bind to the $\mathrm{N}$ terminus of $\beta$-spectrins (Becker et al., 1990, 1993). $\beta$ II spectrin and $\alpha$ II spectrin interact as antiparallel heterodimers, and these heterodimers associate further to form heterotetramers. $\beta$-Spectrins also bind to actin to create a stable and flexible actin-spectrin cytoskeletal network (De Matteis and Morrow, 2000; Bennett and Baines, 2001). Ankyrins interact with $\beta$-spectrins near the $C$ terminus of the spectrin protein (Kennedy et al., 1991). Thus, the $\alpha \mathrm{II} / \beta \mathrm{II}$ spectrin tetramer may associate with membrane proteins through both $\mathrm{N}$ - and C-terminal interactions (supplemental Fig. S2, available at www.jneurosci.org as supplemental material).

Ankyrins function as adapter or scaffolding proteins, linking integral membrane proteins to the actin-spectrin cytoskeleton. Does ankyrinB interact with a paranodal junction membrane protein? In our experiments, we were unable to coimmunoprecipitate ankyrinB and Caspr or NF-155. During early development Caspr and ankyrinB do not colocalize. These results suggest that ankryinB is not likely to be a cytoskeletal linker for either 
Caspr or NF-155. In the PNS, ankyrinB has a much more restricted localization than either $\alpha \mathrm{II}$ or $\beta \mathrm{II}$ spectrin, indicating that ankyrinB localization may depend more critically on interactions with some other paranodal junction membrane protein. A variety of transmembrane proteins interact with ankyrinB in polarized cells (Bennett and Baines, 2001). For example, the $\mathrm{Na}^{+} / \mathrm{Ca}^{2+}$ exchanger, $\mathrm{IP}_{3}$ receptor, and $\alpha \mathrm{I}$ and $\alpha \mathrm{II}$ subunits of the $\mathrm{Na}^{+} / \mathrm{K}^{+}$-ATPase have all been shown to interact with ankyrinB (Mohler et al., 2005). Among these, the $\mathrm{Na}^{+} / \mathrm{K}^{+}$ -ATPase is particularly interesting. Studies in Drosophila have shown the $\mathrm{Na}^{+} / \mathrm{K}^{+}$-ATPase is required for normal septate junctions [Drosophila septate junctions are the invertebrate counterpart to the vertebrate paranodal axoglial junction and contain homologs of Caspr (neurexin IV), contactin (Dcontactin), neurofascin (neuroglian), and protein 4.1B (coracle) (Hortsch and Margolis, 2003)], and the $\alpha 1$ and $\alpha 2$ subunits of the $\mathrm{Na}^{+} / \mathrm{K}^{+}$ -ATPase were identified by mass spectrometry in our paranodal protein enriched membrane fraction (Y. Ogawa and M. N. Rasband, unpublished results). Whether the $\mathrm{Na}^{+} / \mathrm{K}^{+}$-ATPase will be important in the function of paranodal junctions remains to be determined.

\section{Organization of the paranodal cytoskeleton is regulated by both extrinsic (glial) and intrinsic (neuronal) mechanisms} Our results show that formation and/or maintenance of the paranodal cytoskeleton requires neuron-glia interactions. However, this was only true for ankyrinB because $\beta$ II spectrin localization was unaffected by loss of Caspr. One explanation for this difference may be that redistribution of Caspr2 into paranodal zones compensates for loss of Caspr and permits binding of protein $4.1 \mathrm{~B}$ and paranodal $\beta \mathrm{II}$ spectrin. If true, then ankyrinB localization depends more critically on neuron-glia interactions involving its putative membrane protein-binding partner rather than $\beta I I$ spectrin.

In cultured hippocampal neurons, $\beta$ II spectrin is located throughout axons but is excluded from initial segments. Thus, $\beta \mathrm{II}$ and $\beta \mathrm{IV}$ spectrin occupy mutually exclusive domains in axons without any neuron-glia interactions. These results suggest that either $\beta \mathrm{IV}$ spectrin excludes $\beta$ II spectrin from initial segments or $\beta$ II spectrin confines $\beta$ IV spectrin to initial segment domains. However, in $q v^{3 J}$ mutant mice lacking nodal $\beta$ IV spectrin (Yang et al., 2004), $\beta$ II spectrin was still excluded from nodes of Ranvier. This suggests that $\beta$ IV spectrin may not actively exclude $\beta$ II spectrin from specific domains. Alternatively, it may be that $\beta$ II spectrin localization is influenced by both intrinsic ( $\beta \mathrm{IV}$ spectrin) and extrinsic (neuron-glia interactions through protein $4.1 \mathrm{~B}$ ) factors. In this case, because paranodes are intact in $q v^{3 J}$ mutant mice, the role of $\beta \mathrm{IV}$ spectrin in restricting the localization of $\beta$ II spectrin might not be apparent.

Of the paranodal cytoskeletal proteins identified here, only ankyrinB localization was dramatically disrupted in Caspr $r^{-1-}$ mice. Similarly, mice with disrupted paranodal junctions have transmembrane proteins (e.g., Kv1 channels and Caspr2) that extend into paranodal zones but remain excluded from nodes (Dupree et al., 1999; Bhat et al., 2001; Poliak et al., 2001). These observations indicate that the paranodal diffusion barrier is lost in mice lacking appropriate axoglial junctions, but the barrier at the node remains. These results may indicate that membrane diffusion barriers, as observed at the node, paranode, and axon initial segment, depend more on ankyrins than spectrins (Nakada et al., 2003).

We have shown that a specialized paranodal cytoskeleton flanks nodes of Ranvier and that its organization depends on neuron-glia interactions. Therefore, demyelination may have important consequences on the overall structure and/or stability of the axonal cytoskeleton. Previous studies have shown that loss of nodal $\beta$ IV spectrin (i.e., a disrupted nodal cytoskeleton) alters axon shape and axonal neurofilament density throughout the axon (Yang et al., 2004). Disruption of the paranodal cytoskeleton may lead to axons more susceptible to injury or disease. Consistent with this idea, axon loss is believed to be a major cause of symptoms seen in the CNS demyelinating disease multiple sclerosis (Bjartmar and Trapp, 2003). Future experiments designed to disrupt this cytoskeletal complex without interfering with trans interactions between glial and axonal CAMs should reveal the importance of the paranodal cytoskeleton for formation and maintenance of paranodal axon-glia interactions, axon integrity, bidirectional signaling, and the formation of paranodal membrane diffusion barriers.

\section{References}

Arroyo EJ, Xu T, Poliak S, Watson M, Peles E, Scherer SS (2001) Internodal specializations of myelinated axons in the central nervous system. Cell Tissue Res 305:53-66.

Becker PS, Schwartz MA, Morrow JS, Lux SE (1990) Radiolabel-transfer cross-linking demonstrates that protein 4.1 binds to the $\mathrm{N}$-terminal region of beta spectrin and to actin in binary interactions. Eur J Biochem 193:827-836.

Becker PS, Tse WT, Lux SE, Forget BG (1993) Beta spectrin kissimmee: a spectrin variant associated with autosomal dominant hereditary spherocytosis and defective binding to protein 4.1. J Clin Invest 92:612-616.

Bennett V, Baines AJ (2001) Spectrin and ankyrin-based pathways: metazoan inventions for integrating cells into tissues. Physiol Rev 81:1353-1392.

Berghs S, Aggujaro D, Dirkx R, Maksimova E, Stabach P, Hermel JM, Zhang JP, Philbrick W, Slepnev V, Ort T, Solimena M (2000) betaIV spectrin, a new spectrin localized at axon initial segments and nodes of ranvier in the central and peripheral nervous system. J Cell Biol 151:985-1002.

Bhat MA, Rios JC, Lu Y, Garcia-Fresco GP, Ching W, St. Martin M, Li J, Einheber S, Chesler M, Rosenbluth J, Salzer JL, Bellen HJ (2001) Axonglia interactions and the domain organization of myelinated axons requires neurexin IV/Caspr/Paranodin. Neuron 30:369-383.

Bjartmar C, Trapp BD (2003) Axonal degeneration and progressive neurologic disability in multiple sclerosis. Neurotox Res 5:157-164.

Bloch RJ, Morrow JS (1989) An unusual beta-spectrin associated with clustered acetylcholine receptors. J Cell Biol 108:481-493.

Boiko T, Rasband MN, Levinson SR, Caldwell JH, Mandel G, Trimmer JS, Matthews G (2001) Compact myelin dictates the differential targeting of two sodium channel isoforms in the same axon. Neuron 30:91-104.

Boyle ME, Berglund EO, Murai KK, Weber L, Peles E, Ranscht B (2001) Contactin orchestrates assembly of the septate-like junctions at the paranode in myelinated peripheral nerve. Neuron 30:385-397.

Charles P, Tait S, Faivre-Sarrailh C, Barbin G, Gunn-Moore F, DenisenkoNehrbass N, Guennoc AM, Girault JA, Brophy PJ, Lubetzki C (2002) Neurofascin is a glial receptor for the paranodin/Caspr-contactin axonal complex at the axoglial junction. Curr Biol 12:217-220.

Chiu SY, Ritchie JM (1980) Potassium channels in nodal and internodal axonal membrane of mammalian myelinated fibres. Nature 284:170-171.

Davis JQ, Bennett V (1994) Ankyrin binding activity shared by the neurofascin/L1/NrCAM family of nervous system cell adhesion molecules. J Biol Chem 269:27163-27166.

De Matteis MA, Morrow JS (2000) Spectrin tethers and mesh in the biosynthetic pathway. J Cell Sci 113:2331-2343.

Denisenko-Nehrbass N, Oguievetskaia K, Goutebroze L, Galvez T, Yamakawa H, Ohara O, Carnaud M, Girault JA (2003) Protein 4.1B associates with both Caspr/paranodin and Caspr2 at paranodes and juxtaparanodes of myelinated fibres. Eur J Neurosci 17:411-416.

Devaux JJ, Kleopa KA, Cooper EC, Scherer SS (2004) KCNQ2 is a nodal $\mathrm{K}^{+}$ channel. J Neurosci 24:1236-1244.

Dupree JL, Girault J-A, Popko B (1999) Axo-glial interactions regulate the localization of axonal paranodal proteins. J Cell Biol 147:1145-1151.

Eshed Y, Feinberg K, Poliak S, Sabanay H, Sarig-Nadir O, Spiegel I, Bermingham JR Jr, Peles E (2005) Gliomedin mediates schwann cell-axon inter- 
action and the molecular assembly of the nodes of ranvier. Neuron $47: 215-229$.

Garrido JJ, Giraud P, Carlier E, Fernandes F, Moussif A, Fache MP, Debanne D, Dargent B (2003) A targeting motif involved in sodium channel clustering at the axonal initial segment. Science 300:2091-2094.

Gollan L, Sabanay H, Poliak S, Berglund EO, Ranscht B, Peles E (2002) Retention of a cell adhesion complex at the paranodal junction requires the cytoplasmic region of Caspr. J Cell Biol 157:1247-1256.

Gollan L, Salomon D, Salzer JL, Peles E (2003) Caspr regulates the processing of contactin and inhibits its binding to neurofascin. J Cell Biol 163:1213-1218.

Hering H, Lin CC, Sheng M (2003) Lipid rafts in the maintenance of synapses, dendritic spines, and surface AMPA receptor stability. J Neurosci 23:3262-3271.

Hortsch M, Margolis B (2003) Septate and paranodal junctions: kissing cousins. Trends Cell Biol 13:557-561.

Jenkins SM, Kizhatil K, Kramarcy NR, Sen A, Sealock R, Bennett V (2001) FIGQY phosphorylation defines discrete populations of L1 cell adhesion molecules at sites of cell-cell contact and in migrating neurons. J Cell Sci 114:3823-3835.

Kennedy SP, Warren SL, Forget BG, Morrow JS (1991) Ankyrin binds to the 15th repetitive unit of erythroid and nonerythroid beta-spectrin. J Cell Biol 115:267-277.

Kizhatil K, Bennett V (2004) Lateral membrane biogenesis in human bronchial epithelial cells requires $190-\mathrm{kDa}$ ankyrin-G. J Biol Chem 279:16706-16714.

Komada M, Soriano P (2002) [Beta]IV-spectrin regulates sodium channel clustering through ankyrin- $\mathrm{G}$ at axon initial segments and nodes of Ranvier. J Cell Biol 156:337-348.

Lacas-Gervais S, Guo J, Strenzke N, Scarfone E, Kolpe M, Jahkel M, De Camilli P, Moser T, Rasband MN, Solimena M (2004) BetaIVSigma1 spectrin stabilizes the nodes of Ranvier and axon initial segments. J Cell Biol 166:983-990.

Malchiodi-Albedi F, Ceccarini M, Winkelmann JC, Morrow JS, Petrucci TC (1993) The $270 \mathrm{kDa}$ splice variant of erythrocyte beta-spectrin (beta I sigma 2) segregates in vivo and in vitro to specific domains of cerebellar neurons. J Cell Sci 106:67-78.

Mohler PJ, Yoon W, Bennett V (2004) Ankyrin-B targets beta2-spectrin to an intracellular compartment in neonatal cardiomyocytes. J Biol Chem 279:40185-40193.

Mohler PJ, Davis JQ, Bennett V (2005) Ankyrin-B coordinates the Na/K ATPase, $\mathrm{Na} / \mathrm{Ca}$ exchanger, and InsP3 receptor in a cardiac T-tubule/SR microdomain. PLoS Biol 3:e423.

Nakada C, Ritchie K, Oba Y, Nakamura M, Hotta Y, Iino R, Kasai RS, Yamaguchi K, Fujiwara T, Kusumi A (2003) Accumulation of anchored proteins forms membrane diffusion barriers during neuronal polarization. Nat Cell Biol 5:626-632.

Ohara R, Yamakawa H, Nakayama M, Ohara O (2000) Type II brain 4.1 (4.1B/KIAA0987), a member of the protein 4.1 family, is localized to neuronal paranodes. Brain Res Mol Brain Res 85:41-52.

Parkinson NJ, Olsson CL, Hallows JL, McKee-Johnson J, Keogh BP, NobenTrauth K, Kujawa SG, Tempel BL (2001) Mutant beta-spectrin 4 causes auditory and motor neuropathies in quivering mice. Nat Genet 29:61-65.

Poliak S, Peles E (2003) The local differentiation of myelinated axons at nodes of Ranvier. Nat Rev Neurosci 4:968-980.

Poliak S, Gollan L, Martinez R, Custer A, Einheber S, Salzer JL, Trimmer JS, Shrager P, Peles E (1999) Caspr2, a new member of the neurexin superfamily, is localized at the juxtaparanodes of myelinated axons and associates with $\mathrm{K}^{+}$channels. Neuron 24:1037-1047.
Poliak S, Gollan L, Salomon D, Berglund EO, Ohara R, Ranscht B, Peles E (2001) Localization of Caspr2 in myelinated nerves depends on axon-glia interactions and the generation of barriers along the axon. J Neurosci 21:7568-7575.

Poliak S, Salomon D, Elhanany H, Sabanay H, Kiernan B, Pevny L, Stewart CL, Xu X, Chiu SY, Shrager P, Furley AJ, Peles E (2003) Juxtaparanodal clustering of Shaker-like $\mathrm{K}^{+}$channels in myelinated axons depends on Caspr2 and TAG-1. J Cell Biol 162:1149-1160.

Rasband MN, Peles E, Trimmer JS, Levinson SR, Lux SE, Shrager P (1999) Dependence of nodal sodium channel clustering on paranodal axoglial contact in the developing CNS. J Neurosci 19:7516-7528.

Rasband MN, Taylor CM, Bansal R (2003) Paranodal transverse bands are required for maintenance but not initiation of Nav1.6 sodium channel clustering in CNS optic nerve axons. Glia 44:173-182.

Rios JC, Melendez-Vasquez CV, Einheber S, Lustig M, Grumet M, Hemperly J, Peles E, Salzer JL (2000) Contactin-associated protein (Caspr) and contactin form a complex that is targeted to the paranodal junctions during myelination. J Neurosci 20:8354-8364.

Rios JC, Rubin M, St Martin M, Downey RT, Einheber S, Rosenbluth J, Levinson SR, Bhat M, Salzer JL (2003) Paranodal interactions regulate expression of sodium channel subtypes and provide a diffusion barrier for the node of Ranvier. J Neurosci 23:7001-7011.

Salzer JL (2003) Polarized domains of myelinated axons. Neuron 40:297-318.

Schafer DP, Bansal R, Hedstrom KL, Pfeiffer SE, Rasband MN (2004) Does paranode formation and maintenance require partitioning of neurofascin 155 into lipid rafts? J Neurosci 24:3176-3185.

Schafer DP, Custer AW, Shrager P, Rasband MN (2006) Early events in node of Ranvier formation during myelination and remyelination in the PNS. Neuron Glia Biol 2:69-79.

Scotland P, Zhou D, Benveniste H, Bennett V (1998) Nervous system defects of AnkyrinB (-/-) mice suggest functional overlap between the cell adhesion molecule L1 and 440-kD AnkyrinB in premyelinated axons. J Cell Biol 143:1305-1315.

Sherman DL, Tait S, Melrose S, Johnson R, Zonta B, Court FA, Macklin WB, Meek S, Smith AJ, Cottrell DF, Brophy PJ (2005) Neurofascins are required to establish axonal domains for saltatory conduction. Neuron 48:737-742.

Stankewich MC, Tse WT, Peters LL, Ch'ng Y, John KM, Stabach PR, Devarajan P, Morrow JS, Lux SE (1998) A widely expressed betaIII spectrin associated with Golgi and cytoplasmic vesicles. Proc Natl Acad Sci USA 95:14158-14163.

Tandon A, Bannykh S, Kowalchyk JA, Banerjee A, Martin TF, Balch WE (1998) Differential regulation of exocytosis by calcium and CAPS in semi-intact synaptosomes. Neuron 21:147-154.

Tang Y, Katuri V, Dillner A, Mishra B, Deng CX, Mishra L (2003) Disruption of transforming growth factor-beta signaling in ELF beta-spectrindeficient mice. Science 299:574-577.

Tuvia S, Garver TD, Bennett V (1997) The phosphorylation state of the FIGQY tyrosine of neurofascin determines ankyrin-binding activity and patterns of cell segregation. Proc Natl Acad Sci USA 94:12957-12962.

Yang Y, Lacas-Gervais S, Morest DK, Solimena M, Rasband MN (2004) $\beta I V$ spectrins are essential for membrane stability and the molecular organization of nodes of Ranvier. J Neurosci 24:7230-7240.

Zhou D, Lambert S, Malen PL, Carpenter S, Boland LM, Bennett V (1998) AnkyrinG is required for clustering of voltage-gated $\mathrm{Na}$ channels at axon initial segments and for normal action potential firing. J Cell Biol 143: 1295-1304. 